\title{
PARAMETERS OF WHEAT FLOUR, DOUGH, AND BREAD FORTIFIED BY BUCKWHEAT AND MILLET FLOURS
}

\author{
SOŇA GAVURNÍKOVÁ, MICHAELA HAVRLENTOVÁ, LUBOMÍR MENDEL, IVETA ČIČOVÁ, \\ MAGDALÉNA BIELIKOVÁ, JÁN KRAIC
}

Plant Production Research Center Piešt’any

GAVURníkovÁ, S. - HAVRlentovÁ, M. - MENDEL, L. - ČIČOVÁ, I. - BIELIKOVÁ, M. - KRAIC, J.: Parameters of wheat flour, dough, and bread fortified by buckwheat and millet flours. Agriculture (Polnohospodárstvo), vol. 57, 2011, no. 4, pp. 144-153.

The composite flours were created from basic wheat flour and from buckwheat and millet flours used as additives in the weight ratio of $5-30 \%$. Basic technological parameters of flours (ash content, wet gluten, gluten swelling, sedimentation index, falling number), rheological properties of dough, and sensory parameters of baked bread loaves (weight, specific volume, aroma, taste, structure) were studied. Additives influenced all traits of flours, doughs, and baked breads. From the technological and sensory points of view, baked breads with the addition of buckwheat were accepted up to the addition of $20 \%$ and breads with millet up to $5 \%$ (even though taste and flavour were accepted up to $15 \%$ addition).

Key words: composite flour, wheat, buckwheat, millet, quality, functional foods

Nutrition manner is one of fundamental factors influencing physiological status of living organisms. Besides the starvation problem in developing countries, foods can solve there also deficiency of microelements (e.g. Fe, Zn, I, vitamin A) in nourishment, e.g. by fortification of wheat flour with absenting elements or compounds, respectively (Akhtar et al. 2011). On the contrary, food scientists and producers in developed countries also try to conduct at present different projects for enhancing health benefit to consumer's organism by so called functional foods. There is no versatile and commonly accepted definition of functional foods (Hasler 2002), nevertheless according to the European approach functional foods are those which demonstrate beneficial effects on health and welfare and could reduce a risk of prevalence of serious diseases. From a practical point of view, the functional food is also the food to which specific compound was supplemented to improve beneficial effects or the food in which some of compounds was substituted by alternative one with a favourable trait (Howlet 2008). Food supplements or additives are substances of various chemical status and different physical traits appropriate for modification and balancing taste, flavour, appearance, consistence, durability, and nutrients content in food. Marco and Rosell (2008) tested composite flours wheat-pea, wheat-soybean and others and stated that a very simple approach to create composite flours for production of improved and functional bakery products is to add flours or extracts from seeds of another plant species to basic, mostly the wheat flour. In this respect, very interesting is the flour from buckwheat (Fagopyrum esculentum Möench) grains containing $7-21 \%$ of proteins, moreover reach of lysine, and moderate level of sterols positively affecting a cholesterol level in blood (Christa \& Soral-Śmietana 2008). The starch from buckwheat grains contains $15-25 \%$ of amylose and the content of total dietary fiber is around $7 \%$. There are also relatively high levels of chemical elements such as potassium, magnesium, calcium, natrium, iron, manganese,

Ing. Soňa Gavurníková, PhD., RNDr. Michaela Havrlentová, PhD., Ing. Iveta Čičová, Ing. Magdaléna Bieliková, doc. RNDr. Ján Kraic, PhD., Plant Production Research Center, 92168 Piešt’any, Bratislavská cesta 122, Slovak Republic. E-mail: gavurnikova@vurv.sk 
zinc, and vitamins $\left(\mathrm{B}_{1}, \mathrm{~B}_{2}, \mathrm{~B}_{6}\right)$ in buckweat. Furthermore, buckwheat seeds contain interesting biologically active compounds, e.g. flavonoids (rutin, quercetin, orientin, vitexin, isovitexin, isoorientin), flavons, phenolic acids, tannins, phytosterols, and fagopyrins. The rutin content is usually in the range of 12-36 $\mathrm{mg}$ per $100 \mathrm{~g}$ of dry matter (Christa \& Soral-Śmietana 2008). Rutin is able to reduce blood pressure, decrease related incidental risk of arteriosclerosis, and possesses high antioxidant activity (Kreft et al. 2006).

Another minor crop the millet (Panicum miliaceum L.) is considered as a raw material for dietary foods production. The millet has a favourable ratio of nutrients approaching to the recommended ratio between proteins, lipids, and sugars (Karabínová et al. 2001).

The wheat flour has a crucial role in manufacturing baked products including bread as the main one. Wheat flour mixed with water has a unique attribute to create dough with three-dimensional structure. Nevertheless, there are differences (caused mainly by cultivar and growing conditions) among wheat flour parameters. They are usually within the range required by relevant technical norms and working standards or can be adjusted to required values by various additives. The raw material for bakery products, beside primary wheat or rye flours, can also contain other additives impacting and regulating technological parameters, moreover essentially influencing functional value of products. The presumption is that specific compounds of natural origin used as additives would not have any significant negative impact on technological parameters of flour and dough, moreover could improve nutritional and functional value of final bakery products.

In accordance with this, the aim of this study was to analyse and compare: i) technological parameters of composite flours (mixture of major component wheat flour and added flours from minor crops known as donors of nutritional quality - buckwheat or millet), ii) rheological parameters of dough made from composite flours, and iii) quality traits of final bakery products (breads).

\section{MATERIAL AND METHODS}

\section{Composite flours}

The major component of composite flour was fine flour from bread wheat (Triticum aestivum L.) ob- tained from the mill of company Penam a. s. (Trnava, Slovakia). Natural additives used for the study of composite flours were flours from grains of buckwheat (Fagopyrum esculentum MOENCH.) cultivar Špačinská 1 and millet (Panicum miliaceum L.) cultivar Unicum (both maintained, multiplied, and provided by the Genebank of the Slovak Republic, Piešt'any, Slovakia). Buckwheat grains were milled after husking, millet grains were milled whole. The weight ratios (w/w) of buckwheat and millet in composite flours were in the range of 5-30\%.

\section{Qualitative parameters of flour, dough, and bread}

The following qualitative parameters in composite flours were evaluated: crude proteins using the combustion Dumas method (according to AACC 46-30.01, 2010, AOAC 992.23, 1997, ICC 167, 2000), wet gluten content and gluten swelling (STN 46 1011, part 9, 1988), total ash content (STN ISO 2171, 2006), Zeleny's sedimentation index (STN ISO 5529, 2000), falling number (STN ISO 3093, 2006), farinograph parameters (water absorption, dough development time, dough stability, dough softening $10 \mathrm{~min}$ after test starting and 12 min after maximal dough consistency, farinograph quality number) (ICC-Standard No. 115/1, 1992), and bakery test (PN 01/07 - formula for bread: flour $250 \mathrm{~g}$, yeasts $12.5 \mathrm{~g}$, sugar $2.5 \mathrm{~g}$, salt $3.75 \mathrm{~g}$, fat $2.5 \mathrm{~g}$, water volume according to water absorption determined using a farinograph).

The flours and doughs were blended in a universal mixer RM 800 A-B (RM Gastro s. r. o., Czech Republic), fermented for $20 \mathrm{~min}$ in a thermostat at $32 \pm 1^{\circ} \mathrm{C}$, followed by rolling, leaving for $10 \mathrm{~min}$ and dividing into two equivalent parts. Formed loaves were fermented for additional $25 \mathrm{~min}$ at $32 \pm 1^{\circ} \mathrm{C}$ and baked for $20 \mathrm{~min}$ at $230^{\circ} \mathrm{C}$ (modular oven Domino, Marton, Slovakia). Evaluation of specific loaf volume (millilitre of volume per 100 grams of loaf), loaf weight, and sensory parameters were evaluated in baked loaves 2 hours after baking and self-cooling. The five-point hedonic scale (Pokorný 1997) was used by seven referees trained for sensory evaluation. They assessed form, crust (colour, thickness, firmness), crumb (colour, hardness, size and uniformity of crumb porosity), aroma, and taste in loaves. The maximal number of points in evaluation was 53 .

The starch content was determined according to Ewers (STN EN ISO 10520, 2002), lipids by Soxhlet 
extraction (STN 46 1011-28, 1988), and total dietary fiber using the total dietary fibre assay procedure (Megazyme International Ireland Ltd.) based on the methods of AOAC 991.43 (1995), AOAC 985.29 (1995), AACC 32-07 (1995), and AACC 32-05 (1995).

All analyses were done in duplicate. The results were statistically evaluated by analysis of variance (ANOVA), multiple comparisons by LSD test using software Statgraphic Plus 7.0.

\section{RESULTS AND DISCUSSION}

Qualitative parameters of composite flours

Quality of bread, bans, rolls, and other baked products depends primarily on qualitative parameters of basic raw materials, especially quantity and quality of proteins, proportion of gluten proteins, content and parameters of starch and enzymatic complex, and other compounds of plant seeds. The buckwheat flour used in composite flours emerges as a donor of higher con-

$\mathrm{T}$ a b 1 e 1

Parameters of flours used for development of composite flours

\begin{tabular}{|l|c|c|c|c|}
\hline Source of flour & $\begin{array}{c}\text { Proteins } \\
{[\%]}\end{array}$ & $\begin{array}{c}\text { Starch } \\
{[\%]}\end{array}$ & $\begin{array}{c}\text { Lipids } \\
{[\%]}\end{array}$ & Total dietary fiber [\%] \\
\hline Basic wheat flour & 13.8 & 58.2 & 1.3 & 3.8 \\
Buckwheat flour & 11.0 & 68.1 & 1.7 & 5.6 \\
Millet flour & 11.6 & 63.4 & 3.6 & 19.9 \\
\hline
\end{tabular}

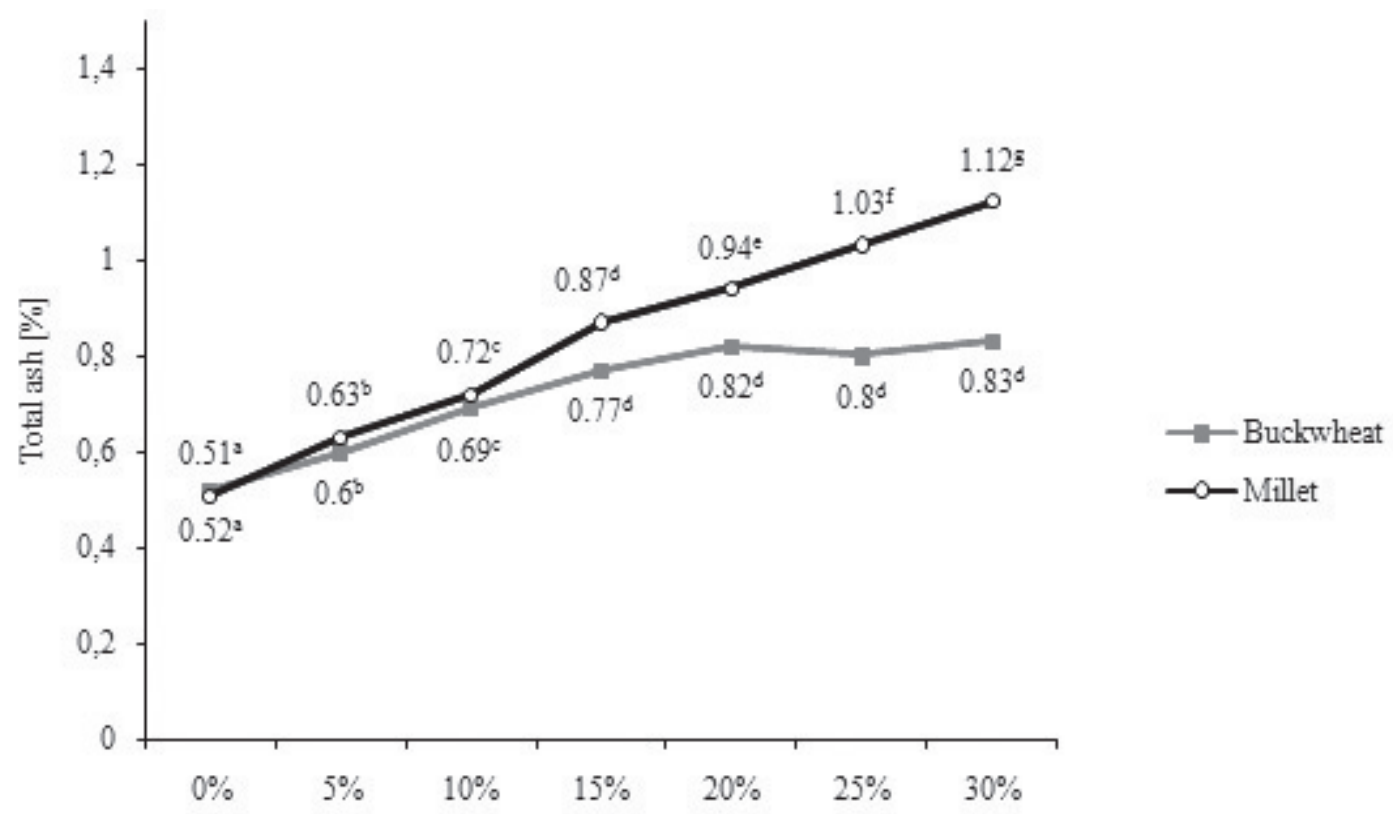

Ratio of buckwheat or millet flour in composite flour [\%]

Fig. 1. Ash content in composite flours wheat-buckwheat, wheat-millet (superscripts represent statistically significant differences at $\mathrm{P}<0.05$ ) 
tent of starch, lipids, and fiber, millet wholemeal flour supplied high amount of fiber (Tab. 1). The ratio of buckwheat or millet in composite flours in the proportion of $5-30 \%(\mathrm{w} / \mathrm{w})$ expressed changes in basic qualitative flour parameters.
Total ash content significantly $(\mathrm{P}<0.05)$ increased in all samples depending on the increased ratio of buckwheat or millet flour, respectively. The composite flour with $30 \%$ of buckwheat or millet flours contained by about $60 \%$ or $120 \%$ more ash content, respectively

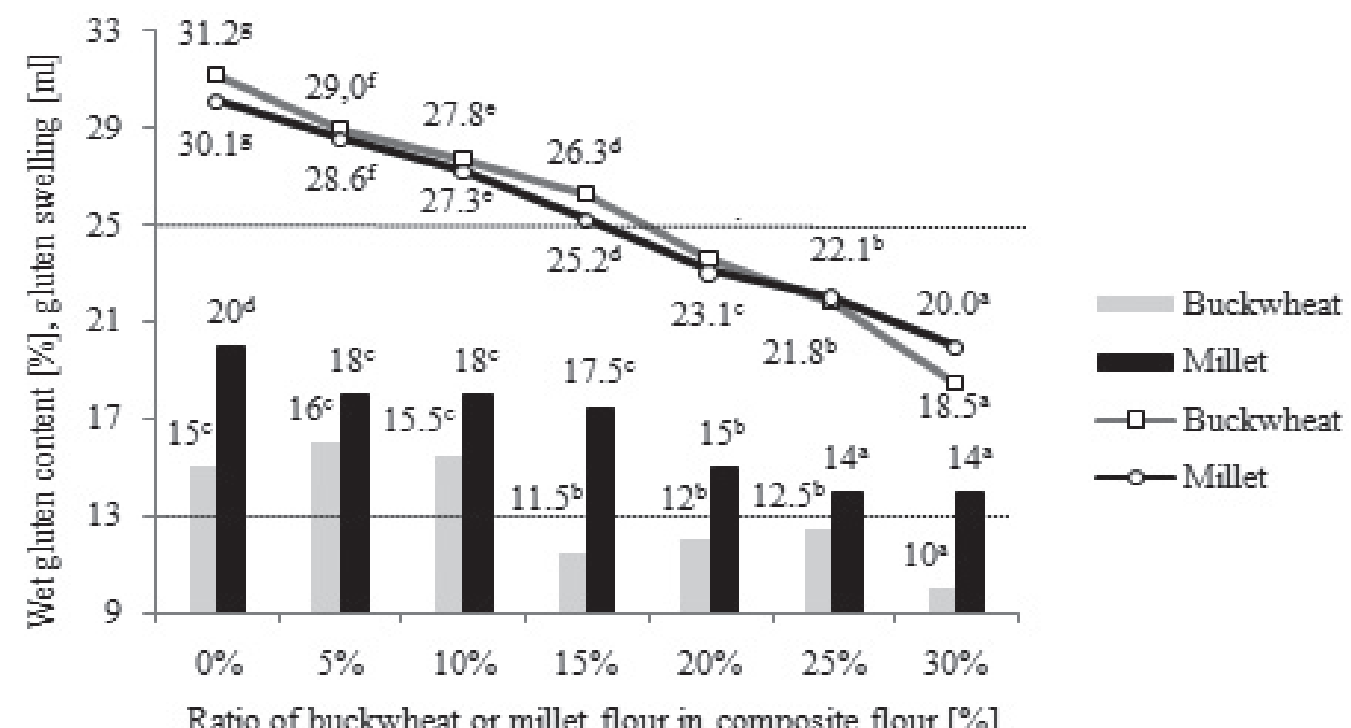

Fig. 2. Wet gluten content (lines) and gluten swellıng (bars) in composite tlours wheat-buckwheat and wheat-millet (superscripts represent statistically significant differences at $\mathrm{P}<0.05$ )

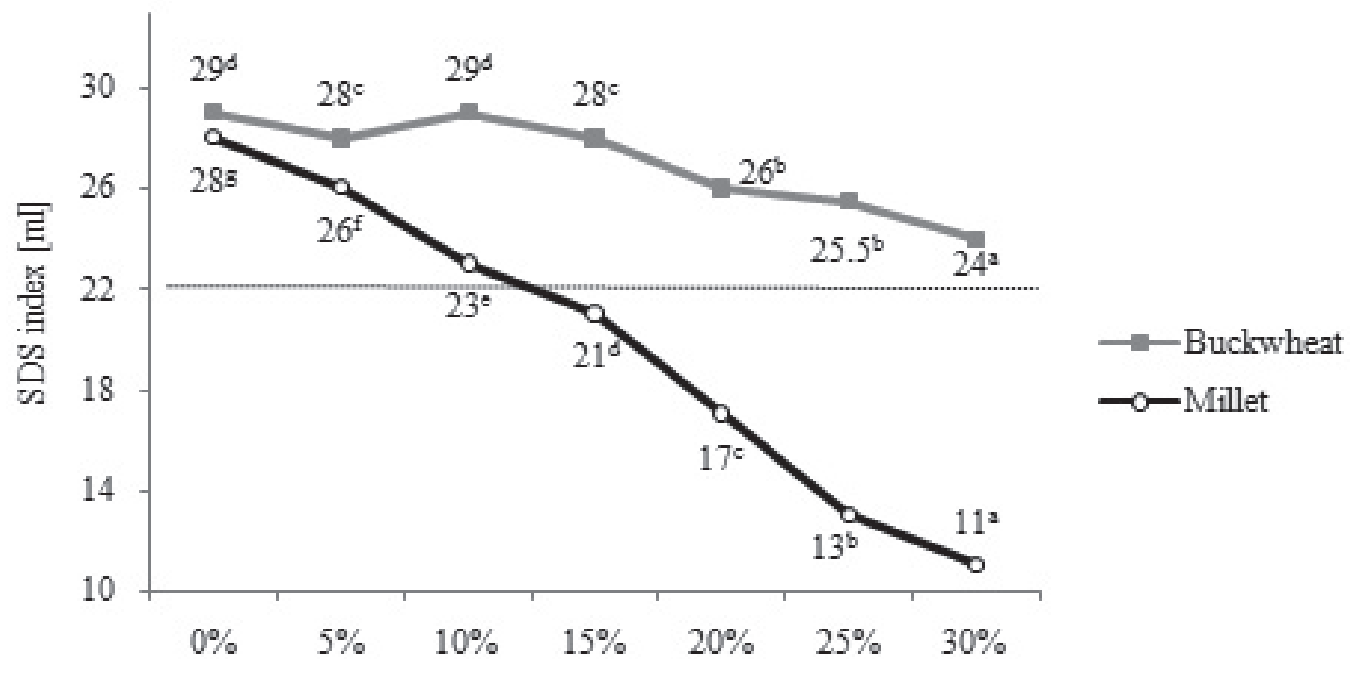

Ratio of buckwheat or millet flour in composite flour [\%]

Fig. 3. Sedimentation index in composite flours wheat-buckwheat and wheat-millet (superscript represent statistically significant differences at $\mathrm{P}<0.05$ ) 
(Fig. 1). Ash content increased significantly $(\mathrm{P}<0.05)$ in wheat-millet flour continually, in wheat-buckwheat only up to the ratio of $15 \%$ of buckwheat, then it was more or less stabilized. The effect of residual ash content in composite flours caused higher amount of noncombustible compounds in buckwheat and mainly in millet blended flours.

The decreasing ratio of wheat in composite flour significantly $(\mathrm{P}<0.05)$ reduced the content of wet gluten (Fig. 2). This is related to the substitution of wheat proteins (gliadins and glutenins) competent to produce viscoelastic gluten by buckwheat or millet proteins which are unable to do this. The wet gluten content was lower than $25 \%$, i.e. the value required by a relevant technical norm for standard bakery quality grade in flours with buckwheat or millet ratio $>15 \%$, respectively. The gluten swelling significantly $(\mathrm{P}<0.05)$ decreased at $15 \%$ ratio of buckwheat flour or $5 \%$ of millet flour, respectively. It may be concluded that each percent of added buckwheat or millet flour reduces gluten swelling by approximately $1 \%$. Nevertheless, in the case that wheat flour is sufficiently strong, neither addition of buckwheat nor millet flour in the ratio up to $30 \%$ should decrease gluten swelling of composite flour below the critical value of $13 \mathrm{ml}$ (Fig. 2).
Both the protein content and gluten quality correlate to sedimentation index. This parameter of composite flours decreased significantly $(\mathrm{P}<0.05)$ along with reduced content of wheat gluten proteins and increased ratios of buckwheat or millet proteins. Nevertheless, the impact of buckwheat flour on the sedimentation index value was lower in comparison to millet flour (Fig. 3). Flours with millet ratio $\geq 15 \%$ had a lower sedimentation index than is the minimal value of 22 $\mathrm{ml}$ required by the relevant technical norm for food wheat (STN 46 1100-2, 2004). In contrast, sedimentation indices of flours with buckwheat in all ratios were above this limit.

The falling number as the parameter of amylolytic activity of grain enzymatic complex increased significantly ( $\mathrm{P}<0.05)$ by addition of $\geq 15 \%$ of buckwheat or $\geq 10 \%$ of millet flour (Fig. 4), which indicates that both buckwheat and millet flours could be used as additives enhancing falling number of wheat flour less usable for bread-making, e.g. the flour produced from wheat cultivated in wet climatic conditions and moreover from cultivars sensitive to sprouting.

\section{Rheological parameters of composite flours}

Farinograph parameters of wheat flour also strongly affect the content and type of proteins (Khatkar

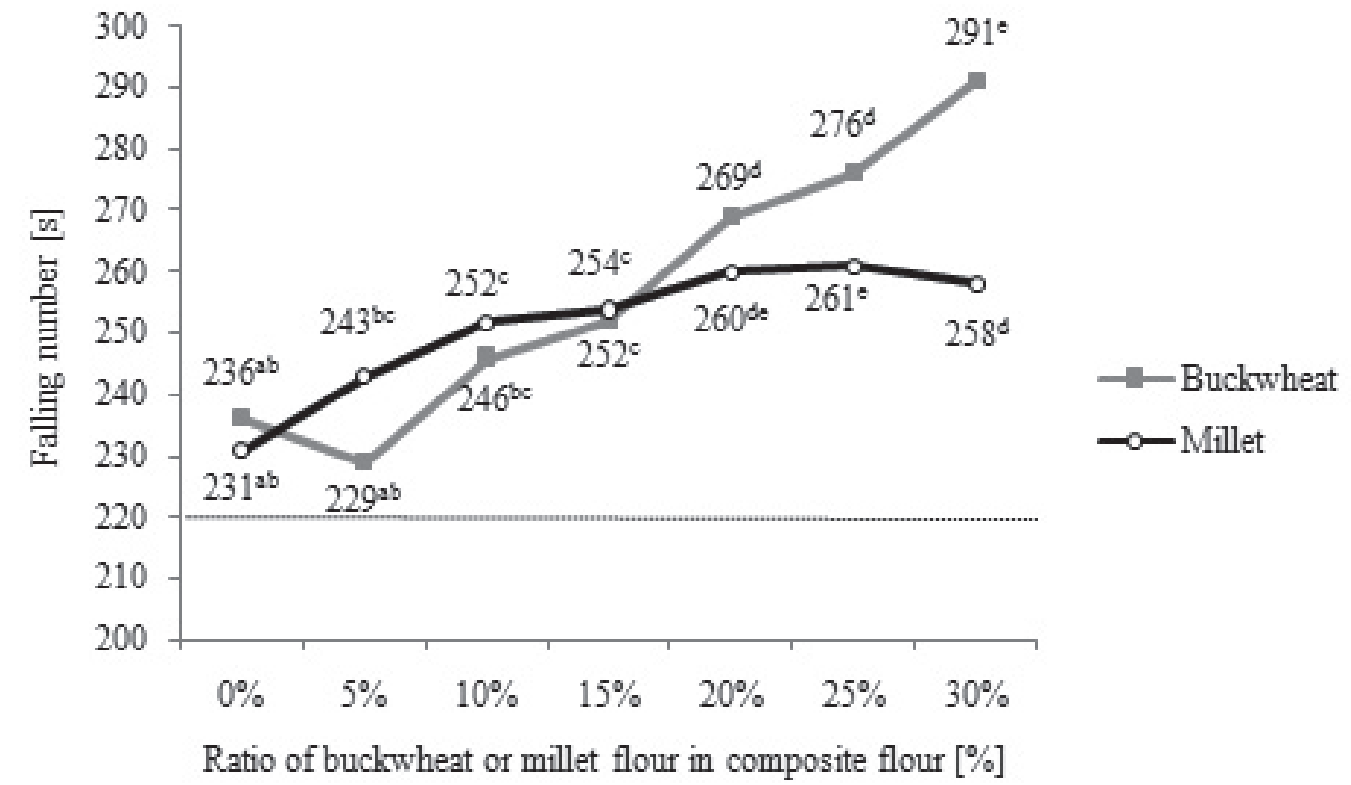

Fig. 4. Falling numbers in composite flours wheat-buckwheat and wheat-millet (superscripts represent statistically significant differences at $\mathrm{P}<0.05$ ) 
et al. 1996; Skendi et al. 2010). The farinograph parameters of created composite flours determined in our study are given in Table 2. Increased content of buckwheat or millet decreased non-significantly $(\mathrm{P}<0.05)$ water absorption. Bojňanská et al. (2009) investigated that the addition of buckwheat up to $20 \%$ decreased water absorption, addition of $30 \%$ did not affect it, and addition of $40 \%$ and $50 \%$ increased this parameter in comparison with control wheat flour. On the contrary, Nikolić et al. (2011) detected non-significant increasing of water absorption in composite flours containing $3-30 \%$ of buckwheat flour. Hadnađev et al. (2008) found moderate reduction of water absorption in mixture with $50 \%$ of buckwheat but moderate increase in mixture with $75 \%$ of buckwheat. These and our results support that the addition of buckwheat flour more or less influences water absorption of composite flours and millet addition reduced this parameter.

The time of dough development decreased after addition $\geq 20 \%$ of buckwheat or $\geq 10 \%$ of millet. Bojňanská et al. (2009) and Nikolić et al. (2011) observed extension of dough development time by ad- dition of buckwheat flour. But unlike our experiment where flour milled only from single buckwheat cultivar (Špačinská 1) was used, Nikolić et al. (2011) used unknown buckwheat flour or flour mixture bought on the local market. The dough stability in composite flours with buckwheat addition was markedly higher than documented by Nikolić et al. (2011). The millet flour addition up to $20 \%$ decreased dough stability, the additions of $25 \%$ and $30 \%$ increased this parameter. The dough softening values after addition of both the buckwheat or millet flours were around the value of control wheat dough. The farinograph quality number (FQN) should be determined from the shape and progress of the farinographic curve. Samples with buckwheat addition reached roughly double FQN values compared to control wheat flour. FQNs indicate that increasing FQN influences dough stability and dough softening parameters. Nikolić et al. (2011) observed the same positive effect of buckwheat flour on FQN but relations to other flour parameters did not reveal. The FQNs of wheat-millet flours were lower in comparison to control wheat flour, except the addi-

$\mathrm{T}$ a $\mathrm{b} 1$ e 2

Rheological parameters of dough from composite flours wheat-buckwheat and wheat-millet

\begin{tabular}{|c|c|c|c|c|c|c|}
\hline Flour & $\begin{array}{c}\text { Water } \\
\text { absorption [\%] }\end{array}$ & $\begin{array}{c}\text { Dough } \\
\text { development } \\
\text { time } \\
\text { [min] }\end{array}$ & $\begin{array}{l}\text { Dough stability } \\
{[\mathrm{min}]}\end{array}$ & $\begin{array}{l}\text { Dough softening } \\
10 \text { min after test } \\
\text { starting } \\
{[\mathrm{BJ}]}\end{array}$ & $\begin{array}{l}\text { Dough softening } \\
12 \text { min after } \\
\text { maximal } \\
\text { consistency } \\
{[\mathrm{BJ}]}\end{array}$ & $\begin{array}{c}\text { Farinograph } \\
\text { quality } \\
\text { number }\end{array}$ \\
\hline Control flour (wheat) & 54.8 & 1.7 & 2.7 & 75 & 82 & 34 \\
\hline $5 \%$ buckwheat & 54.6 & 1.7 & 5.9 & 48 & 67 & 75 \\
\hline $10 \%$ buckwheat & 54.2 & 1.7 & 6.4 & 51 & 71 & 78 \\
\hline $15 \%$ buckwheat & 54.0 & 1.7 & 6.1 & 56 & 76 & 73 \\
\hline $20 \%$ buckwheat & 53.9 & 1.2 & 5.4 & 71 & 89 & 63 \\
\hline $25 \%$ buckwheat & 53.3 & 1.3 & 5.8 & 66 & 84 & 68 \\
\hline $30 \%$ buckwheat & 52.6 & 1.3 & 5.3 & 67 & 84 & 63 \\
\hline Control flour (wheat) & 55.6 & 1.8 & 2.7 & 61 & 75 & 38 \\
\hline $5 \%$ millet & 53.4 & 1.9 & 2.2 & 67 & 80 & 32 \\
\hline $10 \%$ millet & 53.1 & 1.4 & 1.5 & 73 & 87 & 25 \\
\hline $15 \%$ millet & 52.3 & 1.5 & 1.1 & 83 & 95 & 21 \\
\hline $20 \%$ millet & 51.2 & 1.4 & 1.5 & 81 & 93 & 24 \\
\hline $25 \%$ millet & 49.5 & 1.5 & 3.1 & 64 & 77 & 40 \\
\hline $30 \%$ millet & 48.7 & 1.0 & 4.7 & 52 & 68 & 12 \\
\hline
\end{tabular}


tion of $25 \%$ of millet. Similar results were published by Lorenz \& Dilsaver (1980) who evaluated rheological parameters of composite flours containing millet in ratios of $5 \%, 10 \%, 15 \%$, and $20 \%$, where values of water absorption decreased along with increased millet ratio and on the contrary the dough stability and dough softening increased along with increased millet ratio. Supplemented buckwheat flour changed rheological parameters of dough. Significant changes in physical traits of dough by added buckwheat flour were also confirmed by mixographic analyses carried out by Bejosano \& Corke (1998). They ascribed these changes to added buckwheat protein fraction insoluble in water. The reason undoubtedly consists in lower ability of buckwheat proteins to form cross-linked structure in dough in comparison to gluten from wheat flour. It is also supported by lower content and swelling of wet gluten (Fig. 2). The starch and enzyme complex of buckwheat grains increased the falling number (Fig. 4), on the other hand, it also affected rheological properties of composite dough. In comparison with buckwheat or millet addition into the basic wheat flour, we can conclude that wheat-buckwheat composite flours manifested better progress of farinograph curve than in wheat-millet flours.

\section{Influence of buckwheat and millet on bread quality}

The weight of baked loaves was significantly $(\mathrm{P}<0.05)$ higher at the addition of $5 \%$ of buckwheat and significantly $(\mathrm{P}<0.05)$ lower at $15 \%, 20 \%$, and $30 \%$, but all loaves containing millet flour were significantly $(\mathrm{P}<0.05)$ lighter than control wheat ones (Table 3$)$. The specific loaf volume in all buckwheat flour containing loaves was significantly $(\mathrm{P}<0.05)$ lower, additions of $5 \%$ and $15 \%$ of millet flour significantly $(\mathrm{P}<0.05)$ increased loaf volume, additions of $20 \%, 25 \%$, and $30 \%$ of millet significantly $(\mathrm{P}<0.05)$ decreased this parameter (Table 3).

The sensory evaluation of breads revealed that increased ratios of buckwheat and millet flours in composite flour affected almost all of 11 evaluated individual parameters of loaves as follows: shape of loaves - buckwheat neutrally (not affected), millet negatively; colour of crumb - buckwheat positively, millet negatively; crust thickness - both negatively; crust hard-

$\mathrm{T}$ a b 1 e 3

Parameters of baked breads from composite flours wheat-buckwheat and wheat-millet (superscripts represent statistically significant differences at $\mathrm{P}<0.05$ )

\begin{tabular}{|c|c|c|c|c|c|c|c|c|}
\hline \multirow[t]{2}{*}{ Flour } & \multicolumn{4}{|c|}{$\begin{array}{l}\text { Loaf weight after baking } \\
\qquad[\mathrm{g}]\end{array}$} & \multicolumn{4}{|c|}{$\begin{array}{l}\text { Specific loaf volume per } 100 \mathrm{~g} \text { of product } \\
\qquad[\mathrm{ml}]\end{array}$} \\
\hline & $\overline{\mathrm{x}}$ & & SD & & $\overline{\mathrm{x}}$ & & SD & \\
\hline Control flour (wheat) & 180.24 & \pm & 0.4 & $\mathrm{c}$ & 319.0 & \pm & 2.0 & d \\
\hline $5 \%$ buckwheat & 181.02 & \pm & 0.1 & d & 290.0 & \pm & 3.0 & a \\
\hline $10 \%$ buckwheat & 180.15 & \pm & 0.1 & c & 309.5 & \pm & 1.5 & $\mathrm{c}$ \\
\hline $15 \%$ buckwheat & 178.37 & \pm & 0.3 & $\mathrm{~b}$ & 300.0 & \pm & 2.0 & $\mathrm{~b}$ \\
\hline $20 \%$ buckwheat & 178.55 & \pm & 0.2 & $\mathrm{~b}$ & 302.5 & \pm & 5.5 & $\mathrm{~b}$ \\
\hline $25 \%$ buckwheat & 180.34 & \pm & 0.4 & $\mathrm{c}$ & 297.0 & \pm & 2.0 & b \\
\hline $30 \%$ buckwheat & 177.72 & \pm & 0.4 & $\mathrm{a}$ & 309.5 & \pm & 0.5 & $\mathrm{c}$ \\
\hline Control flour (wheat) & 181.05 & \pm & 0.4 & f & 313.5 & \pm & 0.5 & $\mathrm{c}$ \\
\hline $5 \%$ millet & 175.63 & \pm & 0.3 & $\mathrm{e}$ & 321.5 & \pm & 3.5 & d \\
\hline $10 \%$ millet & 175.43 & \pm & 0.1 & $\mathrm{e}$ & 310.5 & \pm & 2.5 & $\mathrm{c}$ \\
\hline $15 \%$ millet & 174.68 & \pm & 0.1 & $\mathrm{~d}$ & 323.5 & \pm & 2.5 & $\mathrm{~d}$ \\
\hline $20 \%$ millet & 173.97 & \pm & 0.1 & c & 282.0 & \pm & 0.0 & a \\
\hline $25 \%$ millet & 171.18 & \pm & 0.2 & $\mathrm{a}$ & 296.5 & \pm & 1.5 & $\mathrm{~b}$ \\
\hline $30 \%$ millet & 172.84 & \pm & 0.1 & $\mathrm{~b}$ & 282.0 & \pm & 1.0 & $\mathrm{a}$ \\
\hline
\end{tabular}


ness - both positively; crust aroma - both negatively; crust taste - buckwheat moderately positive, millet negatively; crumb elasticity, crumb porosity, crumb colour, crumb hardness, and crumb stickiness - both negatively. Nevertheless, statistically significant $(\mathrm{P}<0.05)$ differences in complex sensory parameters of wheat-buckwheat loaves compared to the control were observed only after the ratio of buckwheat was at least $25 \%$ when breads were less accepted by referees (Fig. 5 ). On the contrary, buckwheat addition of 5-10\% by weight neither depreciated technological quality of flour nor sensory parameters of loaves. Similar results were published by Bojňanská et al. (2009). Lin et al. (2009) reported that the substitution of $15 \%$ of wheat flour by buckwheat improved sensory parameters of breads (taste and feeling in mouth). Moreover, rutin and quercetin contained in buckwheat grains increased antioxidant activity of breads, i.e. there is an expected positive effect for consumers of bread. Hromádková et al. (2007) reported loaf quality improvement by addition of hemicelluloses from buckwheat husks and strengthening of standard wheat flour.

The millet addition affected mainly quality of crumb, which was dustier, crumbly, with lower elastic- ity. The taste and aroma of breads changed more significantly $(\mathrm{P}<0.05)$ at $10 \%$ addition and breads were bitter at $25-30 \%$ ratio of millet flour. Statistically significant $(\mathrm{P}<0.05)$ differences in sensory quality of wheat-millet breads were recorded at $10 \%$ ratio of millet. A negative character in wheat-millet breads was "sandiness" occuring in crumb at 5\% addition of millet. Mild particles of millet flour were felt in crumb at chewing as a consequence of higher ash content in millet flour. The same was observed by Badi and Hoseney (1976) in biscuits with millet content. Nevertheless, taste and aroma of wheat-millet breads were accepted by referees up to $15 \%$ ratio of millet as also published by Lorenz \& Dilsaver (1980).

Within the designing of composite flours based on wheat flour as the primary matrix and the buckwheat or miller flours as supplements, an optimal ratio between them with appropriate or acceptable technological parameter can be identified. Composite flours created from wheat and other crops (spelt wheat, oats, barley, rye, buckwheat, soybean, banana, sorghum, amaranth, and others) are considered as a very simple and effective strategy for the improvement of nutritional and functional traits of bakery products (Olaoye

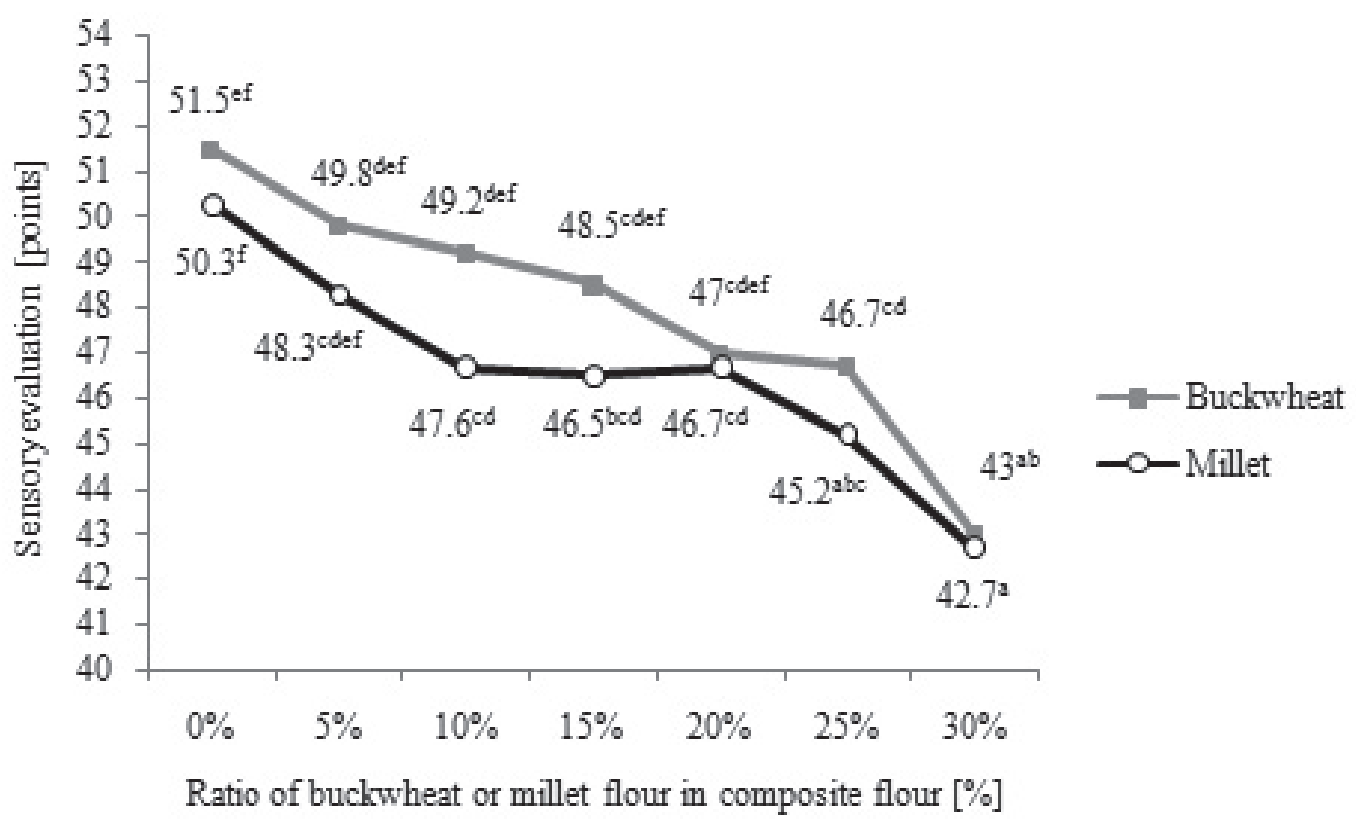

Fig. 5. Sensory evaluation of baked breads from composite flours wheat-buckwheat and wheat-millet (superscripts represent statistically significant differences at $\mathrm{P}<0.05$ ) 
et al. 2006; Grobelnik Mlakar et al. 2009; Angioloni \& Collar 2011; Abdelghafor et al. 2011). According to these authors, the buckwheat contributes to such bread with less soluble, resistant starch (resulting in lower glycemic index), minerals, phenolic compounds, and dietary fiber on the one hand but the bread is more tenacious and low sensory accepted on the other hand. Bojňanská et al. (2009) declared that the addition of buckwheat to wheat flour increased minerals content in breads, most significantly zinc, copper, and manganese, whose content in breads with $50 \%$ ratio of buckwheat flour increased 1.63, 1.49, and 1.14 times, respectively. Based on physical parameters of dough and bakery test, they designate $10-20 \%$ as the favourable ratio of buckwheat in composite flour while negative impacts of buckwheat on technological parameters of dough did not manifest markedly. In comparison with control wheat breads, the breads with $10 \%$ of buckwheat flour in our experiment had almost identical weight, very similar loaf volumes and sensory parameters.

\section{CONCLUSION}

Flours of buckwheat and millet enhanced composite flours in the amount of starch, lipids, and total dietary fiber in comparison with wheat flour and especially the millet flour containing 2.8 times higher content of lipids and 5.2 times higher amount of fiber than wheat. Additions of buckwheat and millet into composite flour increased ash content and decreased content and quality of gluten. Both additives decreased sedimentation index, but the buckwheat less than millet flour. The falling number was increased by both additives as a consequence of partial replacement of amylolytic complex from wheat grains.

Both the flours from buckwheat and millet changed parameters of dough by decreasing water absorption, dough development time, and increasing dough stability. Dough softening in all composite flours ranged around the value of control flour. Nevertheless, buckwheat had a lower negative impact on the development of farinograph curve in comparison to millet.

The loaf weight and specific volume of baked loaves were reduced in composite flours with increased content of buckwheat or millet, respectively. Breads containing buckwheat flour were acceptable in sensory parameters up to the buckwheat ratio of $20 \%$. Never- theless, in breads with millet up to $5 \%$ and by taste and aroma up to $15 \%$, respectively, "sandiness" was felt during chewing of this bread, especially in crumb.

Acknowledgements. This work was supported by OP Research and Development: Development of new types of genetically modified plants with agricultural characters. No: ITMS 26220220027 from European Regional Development Fund.

\section{REFERENCES}

AACC Method 32-05. 1995. Total dietary fiber. Approved methods of the American Association of Cereal Chemists, 9th ed. The Association, St. Paul, MN, 1995.

AACC Method 32-07. 1995. Determination of soluble, insoluble and total dietary fiber in foods and food products. Approved methods of the American Association of Cereal Chemists, 9th ed. The Association, St. Paul, MN, 1995.

AACC Method 46-30.01. 2010. Crude protein - Combustion method. AACC International. Approved methods of analysis, 11th ed. Method 46-30.01. Available online only. AACC International, St. Paul, MN. 2010.

ABDELGHAFOR, R.F. - MUSTAFA, A.I. - IBRAHIM, A.M.H. - KRISHNAN, P.G. 2011. Quality of bread from composite flour of sorghum and hard white winter wheat. In Advance Journal of Food Science and Technology, vol. 3, 2011, no. 1, pp. 9-15.

AKHTAR, S. - ANJUM, F.M. - AKBAR ANJUM, M. 2011. Micronutrient fortification of wheat flour: Recent development and strategies. In Food Research International, vol. 44, 2011, no. 3, pp. 652-659. DOI: 10.1016/ j.foodres.2010.12.033.

ANGIOLONI, A. - COLLAR, C. 2011. Nutritional and functional added value of oat, Kamut ${ }^{\circledR}$, spelt, rye and buckwheat versus common wheat in breadmaking. In Journal of the Science in Food and Agriculture, vol. 91, 2011, no. 7, pp. 1283-1292. DOI: $10.1002 /$ jsfa. 4314 .

AOAC Official Method 985.29. 1995. Total dietary in foods - Enzymatic-gravimetric method. Official methods of analysis, 16th ed. AOAC International, Gaithersburg, MD, 1995.

AOAC Official Method 991.43. 1995. Total, insoluble and soluble dietary fiber in food - Enzymatic-gravimetric method, MES-TRIS buffer. Official methods of analysis, 16th ed. AOAC International, Gaithersburg, MD, 1995.

AOAC Official Method 992.23. 1997. Crude protein in cereal grains and oilseed: Generic combustion method. Official methods of analysis. AOAC International. Maryland, 1997.

BADI, S.M. - HOSENEY, R.C. 1976. Use of sorghum and pearl millet flours in cookies. In Cereal Chemistry, vol. 53, 1976, no. 5, pp. 733-738.

BEJOSANO, F.P. - CORKE, H. 1998. Effect of Amaranthus and buckwheat proteins on wheat dough properties and noodle quality. In Cereal Chemistry, vol. 75, 1998, no. 2, pp. $171-176$. 
BOJŇANSKÁ, T. - FRANČÁKOVÁ, H. - GAŽAR, R. 2009. Vplyv prídavku pohánky na technologickú a nutričnú kvalitu chleba. In Acta fytotechnica et zootechnica, vol. 12, 2009, Special Issue, pp. 57-63.

CHRISTA, K. - SORAL-ŚMIETANA, M. 2008. Buckwheat grains and buckwheat products - nutritional and prophylactic value of their components - a review. In Czech Journal of Food Science, vol. 26, 2008, no. 3, pp. 153-162.

GROBELNIK MLAKAR, S. - BAVEC, M. - TURINEK, BAVEC, F. 2009. Rheological properties of dough made from grain amaranth-cereal composite flours based on wheat and spelt. In Czech Journal of Food Science, vol. 27, 2009, no. 5, pp. 309-319.

HADNAĐEV, M. - TORBICA, A. - DOKIĆ, P. - SAKAČ, M. 2008. Influence of partial wheat flour substitution by buckwheat flour on dough rheological characteristics measured using Mixolab. In Food Processing, Quality and Safety, vol. 35, 2008, no. 3, pp. 129-134.

HASLER, C.M. 2002. Functional foods: Benefits, concerns and challenges - A position paper from the American Council on Science and Health. In The Journal of Nutrition, vol. 132, 2002, no.12, pp. 3772-3781.

HOWLETT, J. 2008. Functional foods from science to health and claims. ILSI Europe, Brussels, Belgium: International Life Sciences Institute, 2008. 44 pp. ISBN 9789078637110

HROMÁDKOVÁ, Z. - STAVOVÁ, A. - EBRINGEROVÁ, A. - HIRSCH, J. 2007. Effect of buckwheat hull hemicelluloses addition on the bread-making quality of wheat flour. In Journal of Food and Nutrition Research, vol. 46, 2007, no. 4, pp. 158-166.

ICC STANDARD No. 115/1. 1992. Method for using the Brabender farinograph. International Association for $\mathrm{Ce}$ real Science and Technology. 1992.

ICC STANDARD No. 167. 2000. Determination of crude protein in grain and grain products for food and feed by the Dumas combustion principle. International Association for Cereal Science and Technology. 2000.

KARABÍNOVÁ, M. - MOLNÁROVÁ, J. - ŽEMBERY, J. 2001. Obilniny III, pestovanie kukurice, ciroku, prosa a pohánky. Kuriér plus Reklama s. r. o., 2001, 91 pp. ISBN 80-88843-23-5.

KHATKAR, B.S. - BELL, A.E. - SCHOFIELD, J.D. 1996. A comparative study of the interrelationships between mixograph parameters and bread-making qualities of wheat flours and glutens. In Journal of the Science of Food and Agriculture, vol. 72, 1996, no. 1, p. 71-85. DOI: $\quad 10.1002 /(\mathrm{SICI}) 1097-0010(199609) 72: 1<71::$ AIDJSFA625>3.0.CO;2-4.

KREFT, I. - FABJAN, N. - YASUMOTO, K. 2006. Rutin content in buckwheat (Fagopyrum esculentum Moench) food materials and products. In Food Chemistry, vol. 98, 2006, no. 3 , pp. $508-512$.
LIN L.Y. - LIU, H.M. - YU, Y.W. - LIN, S.D. - MAU, J.L. 2009. Quality and antioxidant property of buckwheat enhanced wheat bread. In Food Chemistry, vol. 112, 2009, pp. 987-991. DOI: 10.1016/j.foodchem.2008.07.022.

LORENZ, K. - DILSAVER, W. 1980. Rheological properties and food application of proso millet flours. In Cereal Chemistry, vol. 57, 1980, no. 1, pp. 21-24.

MARCO, C. - ROSELL, C.M. 2008. Functional and rheological properties of protein enriched gluten free composite flours. In Journal of Food Engineering, vol. 88, 2008, no. 1, 94-103. DOI: $10.1016 / \mathrm{j}$.jfoodeng.2008.01.018.

NIKOLIĆ, N. - SAKAČ, M. - MASTILOVIĆ, J. 2011. Effect of buckwheat flour addition to wheat flour on acylglycerols and fatty acids composition and rheology properties. In LWT - Food Science and Technology, vol. 44, 2011, no. 3, pp. 650-655. DOI: 10.1016/j.1wt.2010.08.017.

OLAOYE, O.A. - ONILUDE, A.A. - IDOWU, O.A. 2006. Quality characteristics of bread produced from composite flours of wheat, plantain and soybeans. In African Journal of Biotechnology, vol. 5, 2006, no. 11, pp. 1102-1106.

POKORNÝ, J. 1997. Metody senzorické analýzy potravin a stanoveni senzorické jakosti. ÚZPI, Praha, 1997, 196 pp.

SKENDI, A. - BILIADERIS, C.G. - PAPAGEORGIOU, M. - IZYDORCZYK, M.S. 2010. Effects of two barley $\beta$-glucan isolates on wheat flour dough and bread properties. In Food Chemistry, vol. 119, 2010, no. 3, pp. 1159-1167. DOI: $10.016 /$ j.foodchem.2009.08.030

STN 46 1100-2. 2004. Potravinárske obilniny. Čast' 2: Zrno potravinárskej pšenice letnej, SÚTN, 2004.

STN 461011 čast' 9. 1988. Zkoušení obilovin, luštěnin a olejnin. Zkoušení obilovin. Stanoveni mokrého lepku. Stanoveni tažnosti lepku. Stanovení bobtnavosti lepku. Účinnost' od 1.7. 1988.

STN 46 1011-28. 1988. Testing of cereals, legumes and oilbearing crops. Oil-bearing crop testing. Fat content determination (n-hexan or petroether extract).

STN EN ISO 10520. 2002. Native starch. Determination of starch content. Ewers polarimetric method (ISO 10520:1997).

STN ISO 5529. 2000. Pšenica. Stanovenie sedimentačného indexu. Skúška podla Zelenyho. SÚTN: Bratislava. 2000. 8 pp.

STN ISO 2171. 2006. Obilniny a mleté výrobky z obilnin. Stanovenie celkového popola. SÚTN: Bratislava. 2006, 8 pp.

STN ISO 3093. 2006. Obilniny. Pšenica, raž, respektíve múky, tvrdá pšenica a tvrdá pšenica semolina. Stanovenie čísla poklesu podl'a Hagberga-Pertena. SÚTN: Bratislava, 2006, 20 pp.

Received: August, $10^{\text {th }}, 2011$ 